Aksana Shupitskaya

\title{
THE REASONS OF ECONOMIC OFFENCES IN BELARUS AND METHODS OF STRUGGLE AGAINST THEM
}

The Republic of Belarus is at a transitive stage of development. In spite of the fact that since the date of the independence declaration of Belarus more than 15 years have passed, the reforming of the legal system still remains one of actual problems of the Republic of Belarus on the present stage of its functioning.

The sphere of economy is a major segment of the state of Belarus. Its main part is the financial system is represented by set of various spheres of financial relations, in the process of which funds of money resources are formed and used. According to item 132 of the Constitution of the Republic of Belarus the financial credit system of the country includes the budgetary system, the bank system, the financial assets of off-budget funds, enterprises, establishments, organizations and citizens.

One of the problems the legal system of the modern Belarusian state faces, which demands a decision, is an increase in the number of offences committed in the sphere of budgetary law, monetary and credit system, taxation and customs. The analysis of the reasons for their commitment enables to reveal effective ways of struggle against them.

Financial offences represent a version of social financial deviations in the legal sphere, connected with the infringement of the financial legislation and the integrity of financial law relations.

Tax offences concern the sphere of financial offences, customs delicts, illegal acts in business. Responsibility for the specified offences is provided by the Code of the Republic of Belarus about administrative offences, statutory acts of the President of the Republic of Belarus, the Criminal Code of the Republic of Belarus.

Financial offences result from several objective and subjective factors, circumstances and reasons. Causality usually understands a genetic relation between separate conditions, kinds and matter forms in processes of their movement and development. 
The causal explanation of socially negative phenomena assumes a multilevel approach. The antisocial behavior in the financial sphere is ultimately caused by the position of the individuals in social strata, as well as contrasts existing in society.

The source of antisocial deviations lies in contradictions in social, economic and public processes. Thus, the stagnation in the economic life of the 1970s and 1980s entailed the spread of such forms of deviant acts as the plunder of public property as well as private companies and citizens, gambling, contraband, illegal business, other forms of shadow economy.

The modern condition of the former Soviet republics including Belarus, is characterized by such a negative process as the split of society into the prosperous and the poor. The formation of the well-to-do layer is connected with grave crimes, above all economic, but also violent. The collapse of the standard of living of an overwhelming part of the population is caused by a sharp rise in prices for foodstuff and essential commodities, reduction of state housing subsidies, the fall of import, and sharp inflationary processes.

At the analysis of conditions and the reasons for social deviations in the financial sphere it is necessary to note the contradictions of various social strata and groups. The modern society is not free from aggravations and conflicts of interests which can arise in the course of interaction of particular enterprises, branches of a national economy, and the society as a whole.

Errors and distortions in management of the various spheres of public relations, infringements of law, democracy and justice principles became a source of negative phenomena in the financial sphere.

Another source of contradictions is the absence of an accurate concept of development financial law relations in the state. Imperfection of the legislation regulating financial relations, in particular, is the evidence thereof. Thus, on the territory of the Republic of Belarus the General Part of the Tax Code is installed though the Especial part of the specified statutory act is absent till now. The legislation in monetary and credit policies, customs and taxation often varies. Quite often legal norms accepted by various lawmaking subjects, contradict each other. The validation of retroactive effect of laws doesn't promote the effectiveness increase of their operation either. The specified reasons of social deviations concern a category of the reasons considered at level of a society, i.e. at macro level. At individual level as the general reason of socially deviating behavior in sphere of a financial system of the state the mismatch of interests of the person and the requirements of a society expressed in social norms act. The occurrence of this mismatch depends both on deformations of the person, and from features of influence of environment on daily behavior of the subject. 
Objective lacks and difficulties of economy, life, and the organizations of a public life, subjective errors and miscalculations are the reasons of many standard offences in financial law relationships.

The essential role in the definition of the individual's form of behavior is also played by insufficiently high level of his/her sense of responsibility and consciousness.

One more factor is the criminalization of a considerable part of society, the presence of the organized crime operating in the sphere of economic law relations.

One of the characteristics of today's stage of development of public relations in the Republic of Belarus is also the fact that the reasons for antisocial behavior recede in consciousness more and more. That is why all of them come under to influence more hard, all of them are more difficult to predicti and eliminate.

At ordinary level to the reasons for the committment of tax offences, customs delicts, forms of the behavior treated as «commercial swindle», i.e. the plunders made by a deceit or breach of confidence, assignment, waste or abusing office position, legalizations of money resources or other property got illegal by, illegal reception of the credit, malicious evasion from repayment of creditor debts, illegal use of a trade mark, deliberate or fictitious bankruptcy, etc., concern deformations in a way of life of individuals which decline them to fulfilment acts. The specified deformations can be connected with the sphere of work and manufacturing, as well as with the sphere of everyday life and free time. In the sphere of acquisition of labour skills, for example, it is they to whom concern insufficient professional skills, neglecting simple work, orientation to submission of labour interests prestigious or mercenary. In the sphere of requirements, interests of deformation are connected with unjustified overestimate of vital inquiries of is material-household character.

The correct position is expressed in the scientific literature about struggle with the economic offences. According to this view struggle against social deviations in legal sphere can expresses and should be carried out in following directions: information, preventive (or preventive), retaliatory (i.e. application of sanctions) and medical and biologic.

The first three methods could be used for the struggle against financial offences.

The use of the information method of struggle against financial offences is based on the following assumption: the committment of currency, tax or customs delicts is connected with ignorance of rules of law. Thereupon significant distribution to a society of the legal information, legal education and legal formation is represented. Legal knowledge of citizens is provided with various means. To number of sources of legal knowledge carry the direct text of the statutory act, the special notice of 
interested persons and establishments, and the message of the text of the legal document through mass media or the reference to the expert. The level of legal knowledge of a concrete person is defined by the quality of the legal information, timeliness and efficiency of its reception.

The prevention of financial offences includes the general, special and individual preventive maintenance of their committment. The general prevention in this case assumes activity of the state, societies, their institutes, directed on resolution of conflicts in sphere of economy, a social life, moral-spiritual sphere. Special prevention is a purposeful influence on the factors connected with separate kinds or groups of social deviations. Individual preventive maintenance - activity concerning the concrete persons which behavior enters the conflict to social norms. Social and economic, legal, cultural-ideological reforms urged to promote elimination of the reasons for committing financial delicts. Economic measures for the prevention from anti-social acts in the financial sphere are an improvement of the national economy as a whole, economic protection of the population's well-being, and the introduction of scientifically proved living wage. The measures positively influencing various social institutions concern social measures: the creation of a cult of family as well as the development of local government. Ideological actions are directed towards the formation moral consciousness in the members of society on the basis of universal values.

In the conditions of the modern legal policy of the Belarus state in the most effective way of struggle against social deviations in the financial sphere admits applications of sanctions. The operating Code of the Republic of Belarus about administrative offences contains interdictions for a large quantity of offences in tax laws, currency regulation, and the monetary and credit and customs policy. As measures thereof administrative-legal influence penalties in the large sizes, deprivation of the special right, confiscation are widely provided. The criminal code of the Republic of Belarus contains section 8 providing the criminal liability for crimes against the property and a procedure of economic activities. They are: illegal opening of accounts outside of the Republic of Belarus, failure to return foreign currency from abroad, defrauding credits or grants, illegal business activity or failure in the indemnification to the creditor attract application to infringers of penalties or right deprivation to occupy certain posts or to be engaged in certain activity, restriction of freedom or its deprivation. Variety of crimes in economic sphere is counted among serious ones and as a unique measure of punishment provides imprisonment, even without possibility of application for suspension or conditional non-use of punishment.

In this case it is necessary to recognize a state position correct in this sphere. Running, businesses is always connected with certain risk. Besides, the danger of 
economic offences lies, first of all, in a damage which they can cause. Accordingly, the position of the legislator providing for economic (including financial) crimes property measures of punishments would look defensible. In 2005 an article has been included in the Criminal code of the Republic of Belarus 88, according to which «the person who has committed a crime, the entailed causing of a damage of a state ownership or to property of the legal person, the share in statutory fund which fund belongs to the state, or essential harm to the state or public interests and not interfaced to an encroachment for a life or health of the person, can be released from criminal responsibility in an order established by the act if it has voluntary indemnified the caused loss (harm), and also has satisfied other conditions of clearing of the criminal liability, provided by the act».

However, the aforesaid article has not been widely used. Besides, this use substantially is at a loss that the named norm can be applied only at a stage of preliminary investigation of crimes, assumes the personal reference with the petition addressed to the President of the Republic Belarus, does not contain instructions for terms of consideration of the petition for clearing of the criminal liability.

The effective utilization of sanctions for the committment of delicts in economic sphere assumes the debugged work law enforcement bodies, having the right of realization of the financial control in the Republic of Belarus. The Committee of the State Control of the Republic of Belarus, first of all, concerns their number, its structure division - Department of financial investigations, the Ministry of Taxes and Tax Collection, its inspections on places, the Ministry of Finance and its bodies on places, National bank, customs bodies, bodies of Office of Public Prosecutor and legal agencies. Perfection of activity of the specified establishment's contacts accurate regulations of their powers, definition of procedure, remedial rules of acceptance them of decisions, the competent personnel selection providing both effective selection and placement of personnel, and increase of their professional level.

The universal way of struggle against social deviations in the sphere of currency, monetary and credit regulations, customs and tax law relationships does not exist. However, it is obvious, that use named above actions in complex will allow substantially to lower level corresponding kinds of delicts, and, means, will promote strengthening of social and economic and legal system of the state. 


\section{Streszczenie}

Jednym ze współczesnych problemów białoruskiego systemu prawnego, który wymaga rozwiązania, jest wzrastająca liczba przestępstw o charakterze ekonomicznym (gospodarczym) popełnianych w obszarze prawa budżetowego, monetarnego i systemu kredytowego, podatkowego oraz celnego. Źródłami takiego stanu rzeczy są sprzeczności wynikające z przekształceń społeczno-ekonomicznych. Ekonomiczna stagnacja, która nastąpiła w latach siedemdziesiątych i osiemdziesiątych była przyczyną rozprzestrzeniania się naruszeń polegających na uszczupleniu majątku publicznego zarówno przez firmy jak i osoby prywatne, hazardzie, nielegalnej działalności gospodarczej oraz innych form szarej strefy. Analiza źródeł przestępstw gospodarczych umożliwia wskazanie efektywnych sposobów walki z nimi. W sferze prawnej powinna ona skupić się na: informowaniu, zapobieganiu, działaniach sanacyjnych (tj. stosowaniu sankcji). 